J. Clin. Chem. Clin. Biochem.

Vol. 18, 1980, pp. 209-21.4

\title{
Quantitative Determination of Clobazam in Serum and Urine by Gas Chromatography, Thin Layer Chromatography and Fluorometry
}

By P. Hajdú, M. Uihlein and D. Damm

Hoechst Aktiengesellschaft, 6230 Frankfurt/Main 80

(Received August 24/October 18, 1979)

\section{Herrn Prof. Dr. Rolf Sammet zu seinem 60. Geburtstag gewidmet}

Summary: The procedures available for determination of clobazam (Frisium, Hoechst) are gas chromatography, fluorometry, and thin-layer chromatography. The study presents detailed descriptions of analytical procedures appropriate for routine determinations in serum and urine, and results from human trials. Moreover, the physicochemical properties of clobazam, viz., solubility, distribution, and protein binding are given.

\section{Bestimmung von Clobazam in Serum und Urin mittels Gaschromatographie, Dünnschichtchromatographie und Fluorometrie}

Zusammenfassung: Die vorliegende Arbeit gibt eine ausführliche Beschreibung von gaschromatographischen, dünnschichtchromatographischen und fluorometrischen Analysenmethoden zur routinemäßigen Bestimmung von Clobazam (Frisium, Hoechst) und seinen wichtigsten Metaboliten in Serum und Urin. Es werden Ergebnisse von Untersuchungen am Menschen präsentiert und darüber hinaus Angaben zu folgenden physikalisch-chemischen Eigenschaften des Präparats gemacht: Löslichkeit, Verteilung und Protein-Bindung.

\section{Introduction}

Methods are described for the determination of the new anxiolytic agent clobazam ${ }^{1}$ ) (a 1,5-benzodiazepine (1)) in serum (gas chromatography and fluorometry) and urine (thin-layer-chromatography). Clinically relevant physico-chemical data are also presented.<smiles>CN1C(=O)CC(=O)N(c2ccccc2)c2ccc(Cl)cc21</smiles>

\section{Gaschromatographic Determination in Serum}

Clobazam and its main metabolite in serum, $\mathbf{N}$-desmethylclobazam, are determined by gas chromatography using procedure already described for 1,4 benzodiazepines (2-4).

1) Frisium ${ }^{\circledR}$, Hoechst Aktiengesellschaft.

\section{Reagents}

Ethyl ether, ethyl acetate, both reagent grade; internal standard: $1 \mathrm{mg} / 1$ diazepam in demineralized water.

\section{Equipment}

Glass stoppered centrifuge tubes volume about $10 \mathrm{ml}$ : glass stoppered test tubes with tapered end after Beckett; Vortex mixer; refrigerating centrifuge; gas chromatograph; integrator HP 3380 .

\section{Processing}

To $1 \mathrm{ml}$ serum in a centrifuge tube add $0.1 \mathrm{ml}$ of the internal standard solution, and mix with $5 \mathrm{ml}$ ethyl ether on a Vortex mixer for $30 \mathrm{~s}$. Centrifuge for $5 \mathrm{~min}$ in a refrigerating centrifuge at $0-5^{\circ} \mathrm{C}$, transfer about $4 \mathrm{ml}$ of the organic phase to a Beckett tube, and evaporate to dryness at about $40{ }^{\circ} \mathrm{C}$ under nitrogen flow. Take up the residue with $50 \mu l$ ethyl acetate, and keep in a refrigerator until analysis.

\section{Gas-chromatography}

Apparatus: $\quad$ Hewlett-Packard 5700 with nitrogen-specific FID $18789 \mathrm{~A}$ and glass-jet

Column: $\quad$ Glass column $1.20 \mathrm{~m} \times 4 \mathrm{~mm}$

Stationary phase: $2 \%$ OV 101 on Chromosorb W/AW-DMCS, $120-150 \mu \mathrm{m}$

Temperature:

Detector: $\quad 300^{\circ} \mathrm{C}$




Carrier gas: $\quad$ Helium
Flow rate: $\quad 40 \mathrm{ml} / \mathrm{min}$
Sample volume applied:
$\quad 1-2 \mu \mathrm{l}$
Duration of analysis:

about $6 \mathrm{~min}$

Figure 1 shows the chromatograms of a serum blank, a serum blank with the addition of $0.05 \mathrm{mg} / \mathrm{l}$ of clobazam and $\mathrm{N}$-desmethylclobazam, and a patient's serum containing $0.2 \mathrm{mg} / \mathrm{l}$ clobazam and $0.11 \mathrm{mg} / \mathrm{l} \mathrm{N}$-desmethylclobazam. Evaluation was carried out with the integrator by an internal standard procedure, in which the peak areas of the compounds to be determined are compared with the peak area of diazepam.

Evaluation may also be performed by comparing the corresponding peak heights in the chromatogram. The linearity of this evaluation method was verified with mixtures of the pure compounds in ethyl acetate in the range 1 to $25 \mathrm{ng}$ injected $(r=0.9992)$.

\section{Precision and accuracy}

Mixtures of clobazam and $\mathrm{N}$-desmethylclobazam were diluted in serum. The serum samples were split in order to obtain six identical dilution series.

These series were analysed consecutively and gave the following results (tab. 1).
Tab. 1. Gas-chromatographic determination of clobazam and $\mathrm{N}$-desmethylclobazam in serum.

\begin{tabular}{llllll}
\hline $\begin{array}{l}\text { Added } \\
(\mathrm{mg} / \mathrm{l})\end{array}$ & $\begin{array}{l}\text { Found } \\
\text { Clobazam } \\
(\mathrm{mg} / \mathrm{l})\end{array}$ & \multicolumn{4}{l}{$\begin{array}{l}\text { N-Desmethylclobazam } \\
\mathrm{mg} / 1\end{array}$} \\
\hline 0.5 & $0.51 \pm 0.012$ & $(2.4 \%)$ & $0.53 \pm 0.016$ & $(3.0 \%)$ \\
0.2 & $0.21 \pm 0.008$ & $(3.8 \%)$ & $0.21 \pm 0.028$ & $(13.0 \%)$ \\
0.1 & $0.100 \pm 0.0033$ & $(3.3 \%)$ & $0.091 \pm 0.009$ & $(9.9 \%)$ \\
0.05 & $0.055 \pm 0.0026$ & $(4.7 \%)$ & $0.052 \pm 0.009$ & $(17.3 \%)$ \\
0.02 & $0.019 \pm 0.0008$ & $(4.2 \%)$ & $0.020 \pm 0.002$ & $(10.0 \%)$ \\
0.01 & $0.011 \pm 0.0010$ & $(9.1 \%)$ & - & - & - \\
Blank* & $0.007 \pm 0.0017$ & \multicolumn{2}{c}{0} & \\
Bias & $+0.004 \pm 0.005 \mathrm{mg} / 1$ & $+0.007 \pm 0.015 \mathrm{mg} / 1$ \\
\hline
\end{tabular}

*The blank value was obtained from a compound interfering with clobazam (retention time $=3.59 \mathrm{~min}$ versus $3.52 \mathrm{~min}$ for clobazam) As the separation of these compounds is extremely difficult and the blank value is only in the order of magnitude of the detection limit, we suggest a correction of the results.

For clobazam, the relative error of the method increases with decreasing values, which is usually the case in chromatographic trace determinations. The absolute errors correlate well and form a straight line, which does not go through the origin. This permits us to describe the error of the method as the sum of a constant and relative error. Thus, the precision of the method calculated for clobazam amounts to $0.002 \mathrm{mg} / 1+2.2 \%$ of the value measured.
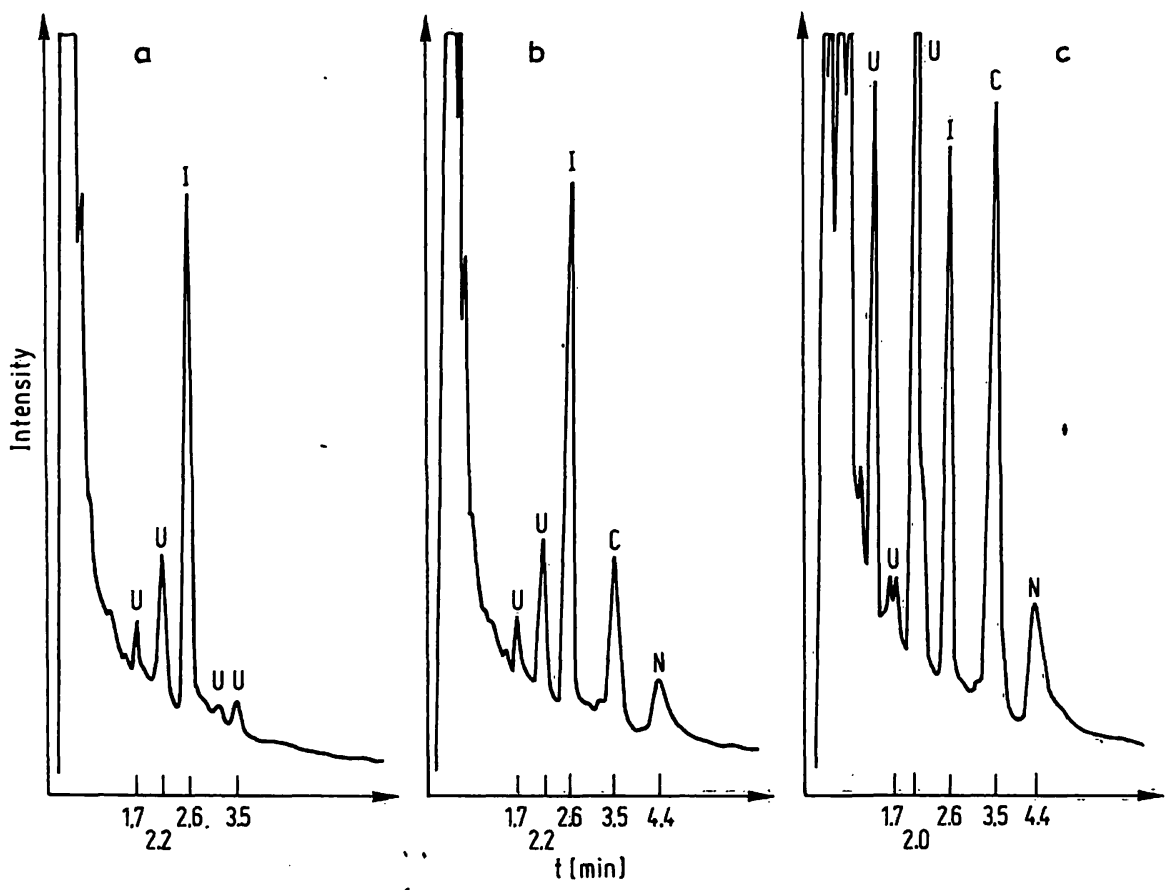

Fig. 1. Determination of clobazam and N-desmethylclobazam in serum by gas chromatography.
a) Serum blank
b) Admixture of $0.05 \mathrm{mg} / \mathrm{l}$ each to serum blank
c) Serum levels after 5 th administration of clobazam
Glass column $1.2 \mathrm{~m} \mathrm{x} 4 \mathrm{~mm} 2 \%$ OV 101 on chromosorb W/AW-DMCS $240^{\circ} \mathrm{C}$ isothermal.
I: Internal standard
C: Clobazam
$\mathrm{N}$ : N-desmethylclobazam
U: Unknown 
Although the above-mentioned correlation is not satisfactory for $\mathrm{N}$-desmethylclobazam, we prefer to describe the error dependency in the same way, resulting in $0.006 \mathrm{mg} / \mathrm{l}+2.5 \%$ of the value measured.

The precision of the method thus obtained enables the limit of detection for quantitative determinations to be easily assessed. If the limit of detection is defined as $t_{p} \times S . D$. (the concentration being 0 ), the following values are obtained: $\left(n=6, t_{p}: 0.05=2.06\right)$

\section{$0.005 \mathrm{mg} / \mathrm{l}$ for clobazam \\ $0.015 \mathrm{mg} / \mathrm{l}$ for $\mathrm{N}$-desmethylclobazam}

\section{Selectivity}

The method measures clobazam and $\mathrm{N}$-desmethylclobazam selectively. The determination of $\mathrm{N}$-desmethylclobazam in therapeutical levels is only possible if a glass column and FID with glass-jet are used. The following synthesized polar metabolites can certainly not be detected in therapeutical levels:

$4^{\prime}$-hydroxyclobazam

$4^{\prime}-\left(3^{\prime}\right)$-hydroxy $-3^{\prime}\left(4^{\prime}\right)$-methoxyclobazam

4'-hydroxy-N-desmethylclobazam

$4^{\prime}-\left(3^{\prime}\right)$-hydroxy-3'(4')-methoxy-N-desmethylclobazam

Results obtained from a multiple-dose human study

In a human study, clobazam was administered to seven volunteer test persons for 10 days daily at 9 a.m. in a dose of $10 \mathrm{mg}$ and at 7 p.m. in a dose of $20 \mathrm{mg}$. The blood samples were taken repeatedly on the first day, and before each administration on the following days. (5).

On the first day, the maximum serum level of clobazam $(0.31 \mathrm{mg} / \mathrm{l})$ was reached two hours after the administration. The elimination half-life was eight hours. $\mathrm{N}$-desmethylclobazam was detected in the blood not earlier than eight hours after administration in a concentration of only $0.05 \mathrm{mg} / \mathrm{l}$.

On the fourth day of treatment, the clobazam levels reached a steady state of $0.90 \pm 0.23 \mathrm{mg} / \mathrm{l}$. $\mathrm{N}$-desmethylclobazam which had a half-life of 50 hours reached a steady state approximately on the 9 th day of treatment at serum levels of $3.6 \pm 1.3 \mathrm{mg} / 1$. An example for the course of serum levels is shown in figure 2.

\section{Fluorometric Determination in Serum}

Clobazam can also be determined by fluorometry. It does not show native fluorescence, but can be transformed into a fluorophore by irradiation with shortwave UV light (6). The advantage of the method is that it is independent of a blank value as the sample is measured before and after irradiation. This transformation shows good reproducibility (cf. 1.c. (7)).

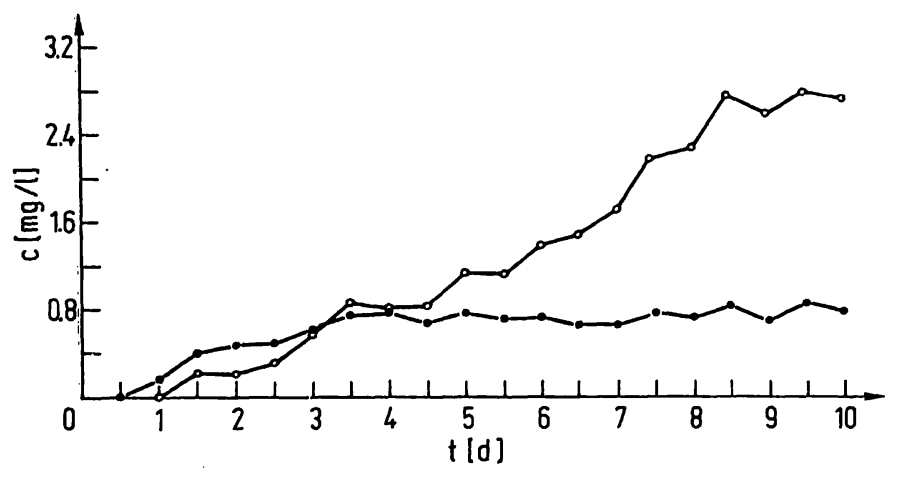

Fig. 2. Concentrations in human serum following multiple dose of clobazam ( $30 \mathrm{mg} / \mathrm{day}$ ).

- clobazam

- N-desmethylclobazam

\section{Reagents}

Ethyl ether, ethyl alcohol, both reagent grade; Standard solution: $0.5 \mathrm{mg} / \mathrm{l}$ clobazam in ethyl alcohol.

\section{Equipment}

Glass stoppered centrifuge tubes, volume about $10 \mathrm{ml}$; Vortex mixer; centrifuge; Pen-Ray lamp 11 Sc 1 (UltraViolet Products, Inc., San Gabriel, California); irradiation chamber with two $1 \mathrm{~cm}$ cells; fluorometer Perkin Elmer MPF 3.

\section{Processing}

To $1 \mathrm{ml}$ serum in a centrifuge tube add $5 \mathrm{ml}$ ethyl ether, and shake for $30 \mathrm{~s}$ on a Vortex mixer. Centrifuge briefly, pipet off $4 \mathrm{ml}$ from the supernatant ether phase into a test tube, and evaporate to dry ness at about $40^{\circ} \mathrm{C}$. under nitrogen flow. Take up the residue with $2 \mathrm{ml}$ ethyl alcohol (sample solution) and keep protected from light until fluorometric measurement.

Fluorometric measurement

Adjustment:

$\begin{array}{lr}\text { Excitation wavelength } & 364 \mathrm{~nm} \\ \text { Excitation slit } & 3 \mathrm{~nm} \\ \text { Emission wavelength } & 400 \mathrm{~nm} \\ \text { Emission slit } & 6 \mathrm{~nm} \\ \text { Sample sensitivity } & 30\end{array}$

Calibration:

In the irradiation chamber, irradiate $2 \mathrm{ml}$ standard solution with UV light in a $1 \mathrm{~cm}$ cell for about one minute. The irradiation time depends on the intensity of the lamp and has to be readjusted from time to time. Adjust the scale reading obtained from the irradiated standard solution to $100 \%$ amplitude by means of the sample adjust button. This adjustment remains unchanged during sample measurement.

Fill the sample solution into a cell and measure (value 1). Subsequently, irradiate the sample solution for exactly the same time as the standard solution and measure again (value 2).

Value 1 (non-irradiated solution) is regarded as blank value and subtracted from value 2 prior to calculation. Calibration curves are established with sera containing standard quantities of the compound. Calibration is linear up to a concentration of $5 \mathrm{mg} / \mathrm{i}$.

\section{Precision and limit of detection}

The data (tab. 2) show a constant precision of the method of $0.016 \mathrm{mg} / 1$ within the concentration range 0.1 to 1.0 $\mathrm{mg} / \mathrm{l}$ serum. Consequently, the limit of detection (cf. paragraph on gas chromatography) is $0.04 \mathrm{mg} / 1$. 
Tab. 2. Results obtained from admixtures to serum.

\begin{tabular}{llr}
\hline $\begin{array}{l}\text { Added } \\
(\mathrm{mg} / \mathrm{l})\end{array}$ & $\begin{array}{l}\text { Found } \\
(\mathrm{mg} / \mathrm{l})\end{array}$ & $\mathrm{n}$ \\
\hline 0.1 & $0.098 \pm 0.013$ & 5 \\
0.2 & $0.200 \pm 0.017$ & 15 \\
0.3 & $0.310 \pm 0.020$ & 5 \\
0.4 & $0.405 \pm 0.013$ & 15 \\
0.5 & $0.500 \pm 0.016$ & 5 \\
0.6 & $0.596 \pm 0.023$ & 10 \\
0.8 & $0.794 \pm 0.018$ & 10 \\
1.0 & $1.005 \pm 0.010$ & 10 \\
& & 17 \\
Blank value & $\emptyset \pm 0.006$ & \\
Bias & $+0.001 \pm 0.005 \mathrm{mg} / 1$ &. .2 \\
\hline
\end{tabular}

\section{Selectivity}

We examined whether the metabolites mentioned above show fluorescence under the same conditions as clobazam: the fluorescence of $\mathrm{N}$-desmethylclobazam amounts only to one third of that of clobazam. 4'-Hydroxyclobazam and $4^{\prime}$ hydroxy-N-desmethylclobazam show one tenth of the fluorescence of clobazam. The two hydroxy-methoxy metabolites show no fluorescence. 1,4-Benzodiażepines do not interfere with the method.

Although the fluorometric method is less specific than gas chromatography, it is a useful alternative for singledose serum kinetics (cf. next paragraph), where these metabolites are only found in negligible serum concentrations (8). Stewart et al. showed (7) that the selectivity can be improved by using hexane as extraction agent.

\section{Comparison of the methods}

The quality of both methods is best demonstrated by parallel determinations in human trials. The results obtained from parallel determinations performed 0 to 24 hours after administration to 10 test persons correlate well (cf. fig.3);

$$
\begin{aligned}
& \mathrm{n}=60 \\
& \mathrm{r}=0.967 \\
& \mathrm{C}_{\mathrm{GC}}=0.96 \times \mathrm{C}_{\mathrm{F} 1}+0.015 \mathrm{mg} / \mathrm{l} \\
& \mathrm{S}_{\mathbf{y} \cdot \mathbf{x}}=\mathrm{S}_{\mathbf{x} . \mathbf{y}}=0.042 \mathrm{mg} / \mathrm{l}
\end{aligned}
$$

It should be mentioned that this correlation exclusively refers to clobazam, because $\mathrm{N}$-desmethylclobazam was found only in negligible amounts.

\section{Thin-layer chromatographic determination in urine}

Clobazam and the main metabolites in man, dog, and monkey - N-desmethylclobazam, 4'-hydroxyclobazam, and $4^{\prime}$-hydroxy-N-desmethylclobazam - can also be quantitatively determined by thin-layer chromatography. The compounds are easily separated on silica gel, using the mobile phase chloroform/n-heptane/methanol $(85 \mathrm{ml}+10 \mathrm{ml}+5 \mathrm{ml})$. Quantitative evaluation is carried

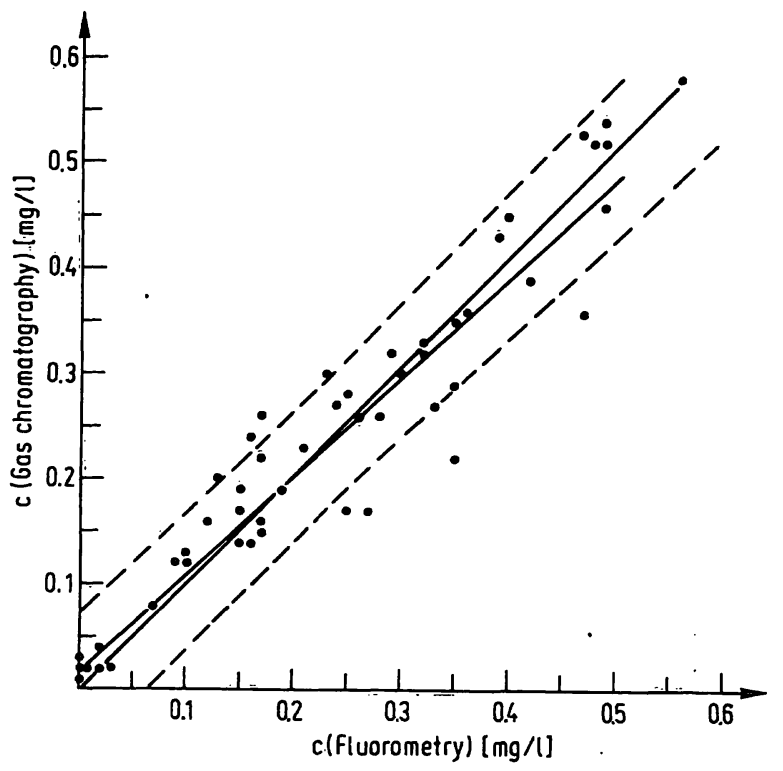

Fig. 3. Correlation of concentrations of clobazam in human serum obtained by gas chromatography and fluorometry.

out by reflectance measurement with the usual TLC evaluating devices (densitometers) at $230 \mathrm{~nm}$.

As a large amount of the metabolites is excreted as conjugates (8), the urine has to be treated with glucuronidase before determination.

\section{Reagents}

Ethyl acetate, chloroform, $n$-heptane, methanol, all reagent grade; acetate buffer $\mathrm{pH} 5.5\left(24 \mathrm{~g} \mathrm{CH}_{3} \mathrm{COONa}+3 \mathrm{H}_{2} \mathrm{O}+\right.$ $240 \mathrm{ml} 0.1 \mathrm{~mol} / 1$ acetic acid/1 $\mathrm{H}_{2} \mathrm{O}$ ); phosphate buffer pH $7.5\left(15.3 \mathrm{~g} \mathrm{Na}_{2} \mathrm{HPO}_{4} \cdot 2 \mathrm{H}_{2} \mathrm{O}+1.9 \mathrm{~g} \mathrm{KH}_{2} \mathrm{PO}_{4} / 1 \mathrm{H}_{2} \mathrm{O}\right.$ saturated with $\mathrm{NaCl}$ ); $0.01 \mathrm{~mol} / \mathrm{l}$ sodium hydroxide solution; $0.01 \mathrm{~mol} / 1$ hydrochloric acid; $\beta$-glucuronidase (Boehringer, Mannheim); ready-prepared TLC plates Si $60 \mathrm{~F}_{254} 20 \times 20 \mathrm{~cm}$ (silica gel with fluorescence indicator, E. Merck, Darmstadt)

\section{Equipment}

Glass stoppered centrifuge tubes, volume about $10 \mathrm{ml}$; Vörtèx mixer; water bath; centrifuge; Desaga mobile phase trough; Desaga autōspotter; TLC-spectrophotometer PMQII with microoptics (Carl Zeiss); recorder Servogor 310.

\section{Processing}

a) Free compounds

To $1 \mathrm{ml}$ urine in a centrifuge tube add $1 \mathrm{ml}$ phosphate buffer pH 7.5, and mix with $5 \mathrm{ml}$ ethyl acetate on a Vortex mixer for $30 \mathrm{~s}$. Centrifuge for $5 \mathrm{~min}$ at $4,000 \mathrm{rpm}$, transfer about $4.5 \mathrm{ml}$ of the organic phase to a centrifuge tube, treat with $1 \mathrm{ml} 0.01$ $\mathrm{mol} / 1 \mathrm{NaOH}$, and shake again on a Vortex mixer for $30 \mathrm{~s}$. Centrifuge, discard the (lower) aqueous layer, and treat about $4.2 \mathrm{ml}$ of the organic phase with $1 \mathrm{ml} 0.01 \mathrm{~mol} / 1 \mathrm{HCl}$ in the same way. Subsequently, evaporate $4 \mathrm{ml}$ of the organic phase at about $40^{\circ} \mathrm{C}$ under nitrogen flow. Take up the residue with $100 \mu l$ methanol before application.

\section{b) Conjugated compounds}

Treat $1 \mathrm{ml}$ urine in a centrifuge tube with $1 \mathrm{ml}$ acetate buffer pH 5.5 and $5 \mathrm{ml}$ ethyl acetate on a Vortex mixer for $30 \mathrm{~s}$ in order to separate the free compounds. Extraçt ạgain with $5 \mathrm{ml}$ ethyl acetate. Treat the remaining aquẹous phase ${ }^{2}$ ) with $10 \mu l$

\footnotetext{
${ }^{2}$ Addition of calibration compounds is made at this ștäge, since the appropriate glucuronides are not available.
} 
$\beta$-glucuronidase, and digest at $37^{\circ} \mathrm{C}$ in a water bath for $48 \mathrm{~h}$. Subsequently add $1 \mathrm{ml}$ phosphate buffer $\mathrm{pH} 7.5$ and proceed as described under "Free compounds".

\section{Application and development}

The autospotter is able to apply up to 20 samples simultaneously onto a TLC plate, whereby optimal adjustment secures minimal spot size.

Apply onto a plate 14 extracts of samples to be measured, 5 extracts of known admixtures, and a sample of pure substance. Adjustment:

$\begin{array}{lr}\text { Application speed } & 3 \\ \text { Heating } & 3 \\ \text { Ventilation } & 3 \\ \text { Application volume } & 50 \mu 1\end{array}$

The plates are developed simultaneously in a mobile phase of chloroform $/ n$-heptane/methanol $(85 \mathrm{ml}+15 \mathrm{ml}+5 \mathrm{ml})$ at room temperature.

Length of run: $16 \mathrm{~cm}$

Development time: about $100 \mathrm{~min}$

$R_{\mathbf{f}}$ values:

$\begin{array}{ll}\text { Clobazam } & 0.90 \\ \text { N-Desmethylclobazam } & 0.59 \\ \text { 4'-Hydroxyclobazam } & 0.48 \\ \text { 4'-Hydroxy-N-desmethylclobazam } & 0.31\end{array}$

\section{Measurement}

Adjustment of TLC spectrophotometer PMQ II:

Slit length $2 \mathrm{~mm}$, slit width $14 \mathrm{~mm}$ (equivalent to $0.5 \times$ $3.5 \mathrm{~mm}$ with microoptics)

Wavelength

Speed of plate reck

$230 \mathrm{~nm}$

$30 \mathrm{~mm} / \mathrm{min}$

Adjust the plate reck to the first substance spot and scan the plate within the corresponding $\mathbf{R}_{\mathbf{f}}$ range.

\section{Evaluation}

Evaluation on the basis of the peak areas is done by hand or by means of an integrator. For each plate, the calibration is calculated separately from admixtures to urine. Linearity is secured up to a concentration of $1 \mathrm{mg} / 1$ urine. At higher concentrations, either less urine is used or a smaller aliquot is applied onto the plate.

Results from addition of standard substances to urine

Since the original substance is not found in urine (6), only the metabolites were added. These dilutions were split into 21 identical samples and processed as described for free and conjugated compounds. The following results were obtạined (tạb. 3 ).

\section{Free compounds}

Precision for all three metabolites is $0.025 \mathrm{mg} / 1+4 \%$ of value. The limit of detection calculated from this is $0.05 \mathrm{mg} / \mathrm{l}$ (c. f. paragraph on gas chromatography).

\section{Conjugated compounds}

\section{Precision}

$\mathrm{N}$-desmethyl $=0.035 \mathrm{mg} / 1+3 \%$ of value

clobazam

4'-Hydroxy- $\quad 0.065 \mathrm{mg} / 1+1.4 \%$ of value $\quad 0.13 \mathrm{mg} / \mathrm{l}$

clobazam

$4^{\prime}-$ Hydroxy- $\quad 0.025 \mathrm{mg} / 1+2 \%$ of value $\quad 0.05 \mathrm{mg} / 1$

N-desmethyl-

clobazam

$\begin{aligned} & \text { Detection } \\ & \text { limit } \\ & 0.07 \mathrm{mg} / 1 \\ & 0.13 \mathrm{mg} / 1 \\ & 0.05 \mathrm{mg} / 1\end{aligned}$

Tab. 3. Thin-layer chromatographic determination of metabolites of clobazam in urine.

\begin{tabular}{llll}
$\begin{array}{l}\text { Added } \\
(\mathrm{mg} / \mathrm{l})\end{array}$ & $\begin{array}{l}\text { Found } \\
\text { N-Desmethyl- } \\
\text { clobazam } \\
(\mathrm{mg} / \mathrm{l})\end{array}$ & $\begin{array}{l}4^{\prime} \text {-Hydroxy- } \\
\text { clobazam } \\
(\mathrm{mg} / \mathrm{l})\end{array}$ & $\begin{array}{l}4^{\prime} \text {-Hydroxy-N- } \\
\text { desmethylclo- } \\
\text { bazam }(\mathrm{mg} / \mathrm{l})\end{array}$ \\
\hline
\end{tabular}

a) Processed as free compounds

$\begin{array}{rrrr}1.0 & 0.99 \pm 0.06 & 1.00 \pm 0.06 & 0.99 \pm 0.06 \\ 0.5 & 0.48 \pm 0.05 & 0.51 \pm 0.05 & 0.53 \pm 0.06 \\ 0.2 & 0.20 \pm 0.05 & 0.22 \pm 0.03 & 0.24 \pm 0.03 \\ 0.1 & 0.09 \pm 0.01 & 0.10 \pm 0.02 & 0.09 \pm 0.03 \\ & & & \\ \text { Bias } & -0.01 \pm 0.01 & +0.01 \pm 0.01 & +0.01 \pm 0.03\end{array}$

b) Processed as conjugated compounds

\begin{tabular}{|c|c|c|c|}
\hline $\begin{array}{l}2.0 \\
1.0 \\
0.5 \\
0.2 \\
0.1\end{array}$ & $\begin{array}{l}2.00 \pm 0.06 \\
1.01 \pm 0.06 \\
0.53 \pm 0.04 \\
0.18 \pm 0.03 \\
0.09 \pm 0.02\end{array}$ & $\begin{array}{l}1.96 \pm 0.09 \\
1.08 \pm 0.09 \\
0.56 \pm 0.08 \\
0.28 \pm 0.07 \\
0.12 \pm 0.06\end{array}$ & $\begin{array}{l}1.96 \pm 0.09 \\
1.03 \pm 0.07 \\
0.53 \pm 0.07 \\
0.20 \pm 0.03 \\
0.09 \pm 0.03\end{array}$ \\
\hline & \pm 0.02 & $+0.04 \pm 0.05$ & \pm 0.03 \\
\hline
\end{tabular}

Figure 4 shows the cumulative urinary excretion of the conjugated metabolites after a single oral dose of $40 \mathrm{mg}$ clobazam given to a healthy volunteer.

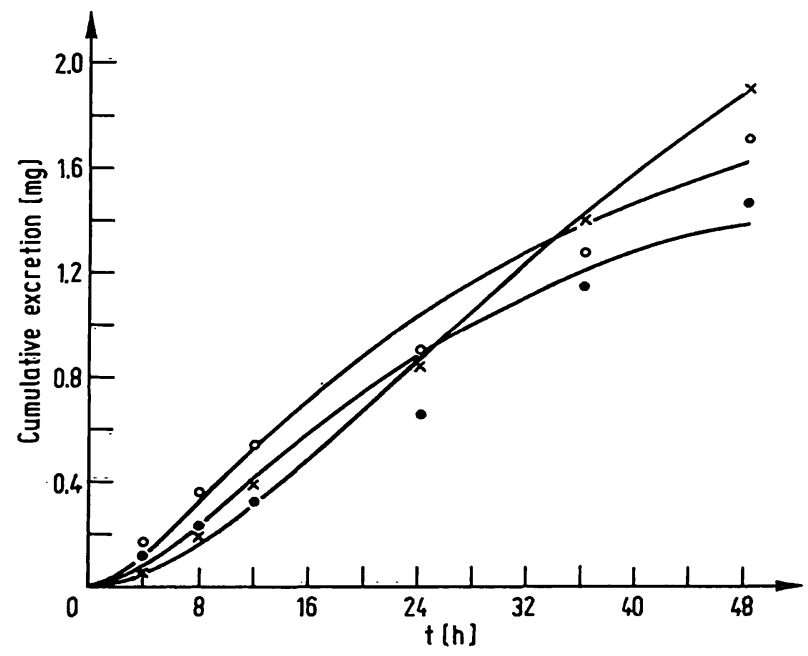

Fig. 4. Cumulative excretion in urine after a single dose of $40 \mathrm{mg}$ clobazam.

Subj. no. 1

$\mathrm{N}$-desmethylclobazam

$\begin{array}{rl}\circ \longrightarrow \mathrm{A} 0=0.032 & \mathrm{~K} 1=2.130 \\ \mathrm{~K} 2=0.360 & \mathrm{~T} 0=0.019 \\ 4^{\prime} \text {-hydroxy clobazam } & \\ \mathrm{X} \mathrm{A} 0=0.017 & \mathrm{~K} 1=4.063 \\ \mathrm{~K} 2=0.099 & \mathrm{~T} 0=0.001\end{array}$

K2 $2=0.099$

$\longrightarrow \quad \mathrm{A} 0=0.038 \quad \mathrm{~K} 1=1.767$

$\mathrm{K} 2=0.206 \quad \mathrm{~T} 0=0.001$ 


\section{Physico-Chemical Data of Clobazam}

Besides the determination methods, the following properties are of clinical interest:

\section{UV absorption spectrum}

The UV spectrum (fig. 5) was taken with a recording spectrophotometer (Beckman Acta M VI) at a concentration of $10 \mathrm{mg} / \mathrm{l}$ in ethanol. It shows a maximum at $228 \mathrm{~nm}\left(\mathrm{~A}_{1}^{1 \mathrm{~g} / \mathrm{dl}}=1450\right)$ and a weak double maximum at 285 and $295 \mathrm{~nm}\left(\mathrm{~A}_{1}^{1 \mathrm{~g} / \mathrm{dm}}=75\right)$.

\section{Solubility}

The solubility in water is $80 \mathrm{mg} / \mathrm{l}$ within the $\mathrm{pH}$ range 3 to 11 .

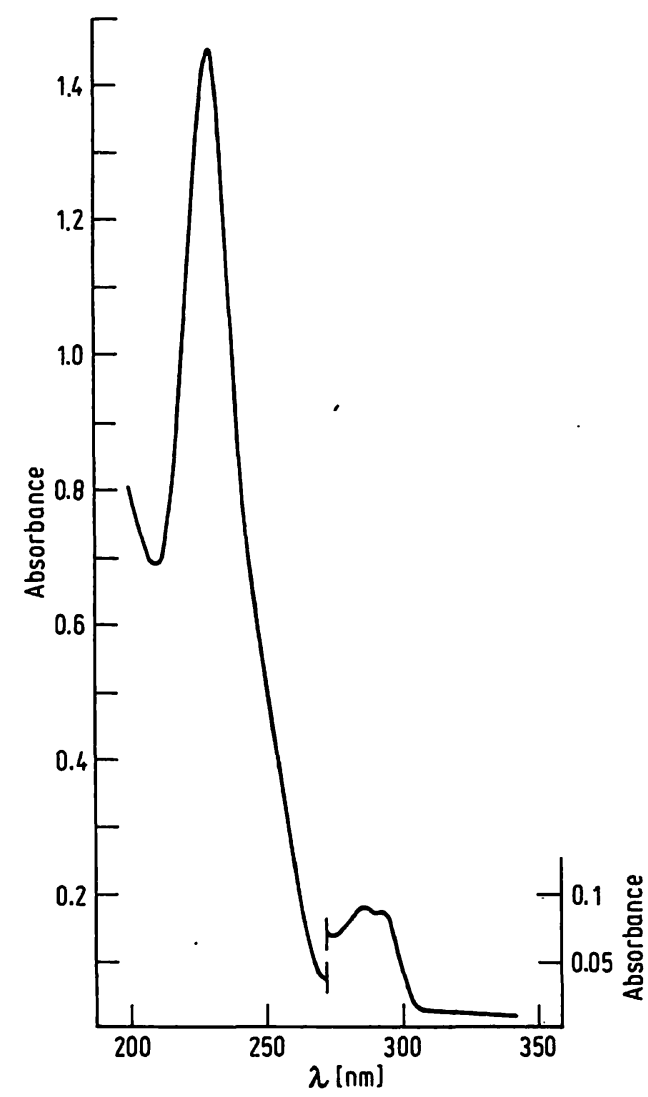

Fig. 5. Absorption spectrum of clobazam ( $10 \mathrm{mg} / \mathrm{l}$ in ethanol) $1 \mathrm{~cm}$ optical pathway.

\section{Distribution}

The compound is freely soluble in lipids. Aqueous buffers containing $5 \mathrm{mg} / \mathrm{l}$ of clobazam and $\mathrm{N}$-desmethylclobazam $(5 \mathrm{mg} / \mathrm{l})$ were extracted with octanol. Within the $\mathrm{pH}$ range 1.2 to 12.4 , both compounds were found practically quantitatively in the organic phase at the distribution equilibrium.

\section{Protein binding}

Protein binding of the compound was determined by equilibrium dialysis according to Scholtan (9). Solutions of $0.125-2.0 \mathrm{mg} / \mathrm{l}$ clobazam in human serum were dialyzed against $0.067 \mathrm{~mol} / \mathrm{l}$ phosphate buffer $\mathrm{pH} 7$ at room temperature overnight. At equilibrium clobazam was determined fluorometrically in serum and the corresponding buffer solutions. The adsorption isotherm after Freundlich (cf. fig. 6) gave the following equation:

$$
\log c_{\text {bound }}=0.925 \times \log c_{\text {free }}+0.780 \pm 0.045
$$

i.e., 85 to 90 percent clobazam is bound to serum protein at therapeutical levels $(0.1-1.6 \mathrm{mg} / 1)$. Similar results were obtained with ultracentrifugation (Centriflo membrane cones from Amicon, Lexington, Mass./USA).

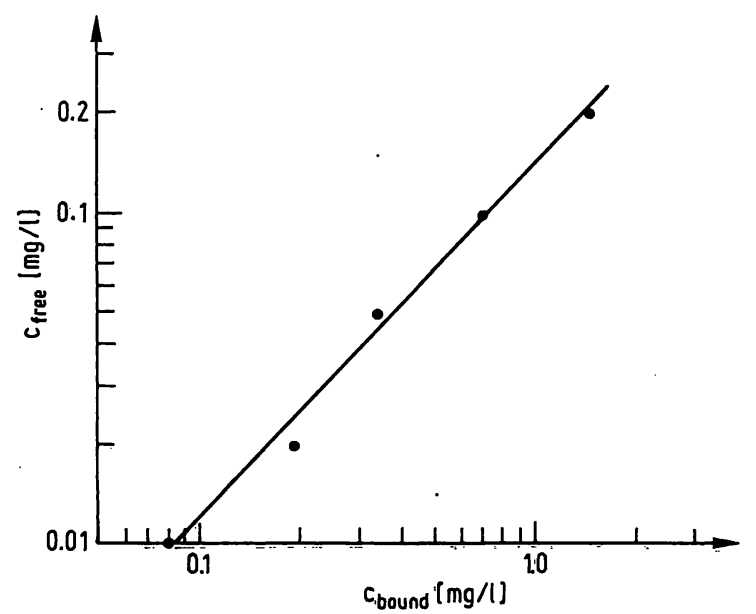

Fig. 6. Protein-binding of clobazam in human serum. $r=0.996$

\section{References}

1. Barzaghi, F., Fournex R. \& Mantegazza, P. (1973) Arzneim.Forsch. 23, 683-686.

2. Marcucci, F. (1968) J. Chromatogr. 37, 318-320. . .

3. de Silva, J. A. F. \& Puglisi, C. V. (1970) Anal. Chem. 42, 1725-1736.

4. Zingales, I. A. (1971), J. Chromatogr. 61, 237-252.

5. Rupp, W., Badian, M., Christ, O., Hajdú, P., Kulkarni, R. D., Taeuber, K., Uihlein, M., Bender, R. \& Vanderbeke, 0. (1979) Br. J. Clin. Pharmac. 7, 51-57.

'6. Hajdú, P. \& Damm, D. (1976), Arzneim.-Forsch. 26, 21412145.

7. Stewart, J. T., Honigberg, I. L., Tsai, A. Y. \& Hajḍu, P. (1979) J. Pharmaceut. Sci. 68, 494-496.

8. Volz, M., Christ, O., Kellner, H.-M., Kuch, H., Fehlhaber, H-W., Gantz, D., Hajdú, P. \& Cavagna, F. (1979) Br. J. Clin. Pharmacol. 7, 41-50.

9. Scholtan, W. (1964) Arzneim.-Forsch. 14, 146-149. 